\title{
Kısa Dönem Kuyu İzlem Verilerine Göre Yeraltısuyu Besleniminin Belirlenmesi, Alaşehir (Manisa) Örneği
}

\section{Groundwater Recharge Estimation Using Short Period Monitoring Level Data, A Case Study Alasehir (Manisa)}

\author{
Celalettin Şimşek ${ }^{1 *}$, Ali Can Demirkesen² ${ }^{(1)}$ \\ ${ }^{1}$ Dokuz Eylül Üniversitesi Torbalı Meslek Yüksekoulu,Torbalı, İzmir, TÜRKIYE \\ 2 İzmir Yüksek Teknolji Enstitüsü, Șehir ve Bölge Planlama Bölümü, Urla, İzmir, TÜRKIYE \\ Sorumlu Yazar / Corresponding Author*: celalettin@deu.edu.trGeliş \\ Tarihi / Received: 28.02.2021 Araștırma Makalesi/Research Article \\ Kabul Tarihi / Accepted:03.06.2021 DOI:10.21205/deufmd.2022247010 \\ Atıf șekli/How to cite:SSIMŞEK, C., DEMIRKESEN, A.C.(2022). Kısa Dönem Kuyu İzlem Verilerine Göre Yeraltısuyu Besleniminin Belirlenmesi, \\ Alaşehir (Manisa) Örneği.DEUFMD, 24(70),91-104 \\ Öz
}

Manisa Alașehir graben sistemi içerisinde yer alan Kuvaterner Alüvyon akiferin ylllık beslenim miktarı yeraltısuyu seviye verilerine göre belirlenmiştir. Bunun için alana 10 adet pompaj kuyusu, 30 adet araştırma kuyusu açılmıştır. Akiferin karekterizasyonu yapılmış ve sahada akifer temsil edecek şekilde kuyulara otomatik seviye kaydedici ve 3 noktada meteoroloji istasyonu kurularak veriler elde edilmiştir. Bir hidrolojik dönemde elde edilen seviye verileri kullanılarak en düşük seviye ve en yüksek seviyeler belirlenmiș ve bu verilerden akiferin beslenim miktarı belirlenmiștir. Seviye izleme verisi sonuçlarına göre akiferin yıllık beslenim değerinin $39,6 \mathrm{~mm}$ ile 588,99 $\mathrm{mm}$ arasında değişmekte ve ortalaması 290 mm'dir. En yüksek beslenme miktarı jeolojik yapıya uyumlu olarak akiferin batı kesimlerindeki geçirimli alüvyonel yelpazelerin dağılım sunduğu alanlarda belirlenmiștir. Seviye değișim yöntemi zaman alıcı ve uzun dönem izleme gerektiren bir yöntem olmasına karşın akiferdeki beslenimin daha doğruya yakın hesaplanmasına yardımcı olan bir yöntem olarak karşımıza çıkmaktadır.

Anahtar Kelimeler: Seviye değişim yöntemi, yeraltısuyu izleme, yeraltısuyu beslenimi

Abstract

The annual recharge of the Quaternary Alluvium aquifer in the Manisa Alaşehir graben system was determined according to groundwater level data. For this purpose, 10 pumping wells and 30 research wells were drilled in the area. The characterization of the aquifer was made and the data were obtained by installing an automatic level recorders in wells and meteorology stations to represent the aquifer in the field. Using the level data obtained in a hydrological period, the lowest level and the highest levels were determined and from these data the recharge of the aquifer was calculated. According to the results of monitoring wells, it has been calculated that the annual recharge value of the aquifer varies between $39,6 \mathrm{~mm}$ and $588,99 \mathrm{~mm}$ with $290 \mathrm{~mm}$ on average. The highest recharge value was determined permeable alluvial fans materials in the western parts of the aquifer in accordance with the geological structure. Although the level change method requires long-term monitoring and time, this method helps us to calculate the inflow in the aquifer more accurately.

Keywords: Level fluctuation method, groundwater monitoring, groundwater recharge 


\section{Giriş}

Son dönemlerde dünya genelinde kuraklık sorunu yaşanmaktadır. Kuraklık dönemlerinde yüzeysel su kaynaklarındaki azalma, tarımsal faaliyetleri, içme-kullanma suyu kullanımına dönük su miktarında azalma ve dolayısı ile insanların sosyo-ekonomik dengesini etkilemektedir [1]. Diğer önemli bir su kaynağımız ise akiferlerde depolanan yeraltısularıdır. Dünya üzerindeki temiz kullanılabilir su kaynaklarımızın \%1'ini yeraltısuyu kaynakları oluşturur [2]. Yeraltısuları yüzeysel su kaynaklarından süzülerek geçirimli ve geometrisi bulunan jeolojik ortamlarda depolanan sulardır. Kullanılan yeraltısuyunun \% 60'ı tarımsal sulamada, sanayi ve içme suyu amaçlı olarak kullanılmaktadır. Bununla birlikte, birçok kurak ve yarı kurak bölgede ise canlıların içme suyu gereksinimi büyük çoğunluğu yeraltısuyuna bağımlıdır [3]. Ülkemiz bu açıdan bakıldığında, iklim ve coğrafik özellikleri dikkate alındığında yarı kurak ve kurak iklim tipine sahip bir kuşakta olup, su azlığı problemi yaşayan bir bölgede yer almaktadır [4]. Bu bağlamda son yıllarda Nehir Havza Yönetim Planları kapsamında yapılan çalışmalar da ülkemizdeki su kaynaklarının hem kalite hem de miktar açısından kullanıma ve iklimsel özelliklere bağlı olarak azalma eğiliminde olduğunu göstermektedir [5]. Yapılan havza bazlı çalıșma sonuçlarına bakıldığında yeraltısuyu kaynaklarına miktar açısından önemli azalmalar tespit edilmiştir. Akiferlerdeki aşırı yeraltısuyu tüketimi, yeraltısuyu seviyelerinde önemli düşümlere neden olmakta ve kurak dönemlerde sulama ve içme-kullanma açısından önemli su problemleri yaşanmaktadır $[6,7]$.

Son ylllarda, stratejik bir öneme sahip olan yeraltısuyunun sürdürülebilir verimliliğinin arttırılması için kalite ve miktarının belirlenmesine yönelik olarak ülkemizdeki tüm havzalarda detaylı hidrojeolojik çalıșmalar yapılmaktadır [8]. Bu çalışmalarda yeraltısuyu potansiyelinin belirlenmesi, kalite ve miktar açısından koruma tedbirlerine yönelik stratejiler araştırılmaktadır. Ancak, yapılan çalışmalarda yașanan en önemli sorunlardan biri akiferde depolanan yeraltısuyunun yıllık beslenme ve boşalım miktarının belirlenmesinde yönelik somut hesaplama yöntemlerinin olmamasıdır. Yeraltısuyu kaynağının sürdürülebilirliğinin planlanmasında en önemli faktör su miktarının belirlenmesidir. $\mathrm{Bu}$ kapsamda akiferdeki yeraltısuyu rezervinin tam olarak belirlenmesi, yıllık beslenme ve çekim miktarının belirlenmesi ve ayrıca en önemli parametreyi oluşturmaktadır. Yeraltısuyunun beslenme miktarının belirlenmesine yönelik somut yöntemlerin geliștirilmemesi ve bir standarda oturtulamaması nedeniyle yeraltısuyu beslenim miktarının belirlenmesi hidrojeolojik çalışmalarda ölçülmesi ve hesaplanması en güç parametrelerden birisini oluşturur [9]. Literatürde bütçe modeli, fiziksel ölçüm yöntemleri, zemin nemi, izleyici ve kimyasal izleme teknikleri (duraylı izotoplar ve çevresel izleyiciler), nümerik modelleme çalışmaları ve yeraltısuyu seviye değişim gibi çok farklı yöntemlerle beslenme değerinin belirlenmesine yönelik çalışma mevcuttur $\left[\begin{array}{ll}10 & -14\end{array}\right]$. Bu yöntemler arasında zaman alıcı fakat en sağlıklı ölçüm yöntemlerinden birini seviye değişim yöntemi oluşturur. Bu yöntemin en önemli özelliği akifere toplam giren (yağıș, yüzeysel su ve yanal beslenim) ve çıkan suyu izleme olanağı tanımaktadır. Ancak bu yöntem için akiferi temsil edecek sayıda izleme ağının kurulması önem taşımaktadır. DSİ tarafından uzun yıllardır özellikle alüvyon akiferlerin beslenme miktarının belirlenmesinde seviye değişim yöntemini kullanılmıștır. Ancak bu beslenim belirlenmesinde kullanılan kuyular geniș yayılımlı akiferlerde sayısal olarak oldukça sınırlıdır. Bu çalıșmada ise akiferi temsil edecek sayıda izleme kuyuları açılarak bir hidrolojik dönemde izleme yapılarak yeraltısuyu seviye değișimi izlenmiș ve bu veriler ıșığında akiferdeki yeraltısuyu beslenimi belirlenmiștir. Çalışma Ege Bölgesindeki akiferleri temsil edecek özelliklere sahip Gediz Havzasının bir alt havzası olan Alașehir alüvyon akiferinde uygulanmıștır (Şekil 1). Bu çalıșmada Tubitak 1003 projesi kapsamında yapılan bir çok beslenme metodolojisi uygulanmış ve burada sadece seviye değișim yöntemi ve elde edilen sonuçlar değerlendirilmiştir.

\section{Materyal ve Methot \\ 2.1. Bölgedeki Akiferlerin Özellikleri}

Projenin uygulandığı akiferi, bölgede Kuvaterner ve Pleyistosen yașlı alüvyon, alüvyonel yelpazeler, ve yamaç molozlarının kapsayan taneli birimler olușturmaktadır (Şekil 1). Jeolojik yapı itibari ile bu tür çöküntü alanlarında depolanan gevşek yapılı taneli 
birimler yeraltısuyu bulundurma ve sağlama açısından oldukça elverișlidir. Proje sahasındaki taneli birimler 581,6 $\mathrm{km}^{2}$ lik bir alanı kapsamakta ve alt havzanın \% 21,45'ini oluşturmaktadır. Yekpare olarak yer alan ovadaki bölgede yapılan su ve jeotermal sondaj verilerine göre birim kalınlığı 24 ile $225 \mathrm{~m}$ arasında değişmektedir. Kuyuların özgül debisi 0,01 ile 22,56 L/s/m arasındadır [6]. Ovada yapılan sondajlarda 200 m'ye kadar kil ve çakıl ardalanmalı olarak devam etmiştir. Alüvyon, doğu kesimlerde ağırlıklı kil, batı kesimlerde ise ağırlıklı kum ve çakıl olarak karşımıza çkmaktadır. Proje sahasında yeraltısuyu kullanımı tamamıla alüvyon akiferden sağlanmaktadır. Alüvyon akiferin altında ise kalınlığı 1000 m'nin üzerinde olan düşük verimli Neojen Kırıntılı birimler yeralmaktadır. Bu birim kiltașı, silttașı, kumtașı ve çakıltașı ardalanmasından oluşmakta ve genel olarak kumtaşı ve çakıltaşı düzeyleri su taşıyan tabakalar olarak karşımıza çıkmaktadır. Havzayı çevreleyen temel kayaları ise ağırlıklı olarak Menderes masifine ait șistlerden olușmakta ve geçirimsiz özelliktedir. $\mathrm{Bu}$ birimlerden yeraltısuyu sağlama olanakları oldukça sınırlıdır. Ancak Menderes masifi içerisindeki mermer tabakalarından graben alanı içerisinde jeotermal su rezervuarı bulunmakta ve bu rezervuardan sıcak su kuyuları ile üretim yapılmaktadır. Bu projenin asıl konusu yeraltısuyu taşıyan akifer olan alüvyonel birimlerdir. Havzanın yapısal özellikleri Ege Bölgesindeki diğer havzalara benzemesi nedeni ile buradan elde edilecek bulgular yeraltısuyu sisteminin araştırılmasında buna benzer akifer sistemlerine ıșık tutacaktır.

\subsection{Yeraltısuyu İzleme Sisteminin Kurulması}

Proje sahasına üç adet meteoroloji istasyonu konumlandırılmıştır. Bu istasyonlardan yağıș miktarı, rüzgâr yönü ve hızı, nem, hava sıcaklık değerleri ölçülmüştür. Ölçümler her saat başı alınacak şekilde ayarlanmış ve veri bankasında depolanmıştır. İstasyonların lokasyon seçimlerinde havzada yer alan DSİ ve Meteoroloji Genel Müdürlüğü istasyonları dikkate alınmıștır. Belirlenen istasyon noktaların alüvyon akiferi temsil edecek şekilde yerleştirilmiştir (Şekil 2).

Proje kapsamında toplam 10 noktada ve derinlikleri 75-125 m arasında değișen ve toplam derinliği $1000 \mathrm{~m}$ olan 10 adet pompaj sondaj kuyusu açılmıştır. Bu kuyuların açılış amaçları, akiferin hidrolik parametrelerinin belirlenmesi için pompa testlerinin yapılması ve bazı kuyulara ise seviye kaydedici yerleștirilerek yeraltısuyu seviye değişiminin izlenmesidir. Ayrıca proje kapsamında açlan kuyulardan su örneklerinin alınması da hedeflenmiştir. Pompaj kuyuları en az 8,5" (21,59 cm) çapla açılmıştır. Proje sahasında akifer litolojisinin tanımlanması, vadoz bölgenin geçirgenlik değerlerinin belirlenmesi, pompaj testleri için açılan pompaj kuyularının 525 m arasında değișen uzaklıklara gözlem kuyusu olarak kullanılması, zemin nem ölçüm sistemlerinin yerleştirilmesi ve akiferden karot alınması için toplamda 30 noktada araştırma kuyusu açılmıştır. Bu açılan kuyuların 10 tanesi pompaj kuyularının yakınlarına açılmış ve pompaj testlerinde seviye ölçümü amaçlı kullanılmıştır. Açılan pompaj kuyularının iki tanesi pompaj testi sırasında gaz gelişi ile birlikte fıșkırma yapmış ve su gelişi durdurulamadığından çimentolanmak zorunda kalınmıştır.

Diğer araştırma kuyularında ise alüvyon akiferin karekterizasyonu için öncelikle karot örneği almak ve daha sonra gözlem kuyusuna dönüştürülmesi hedeflenmiştir. Sondaj tekniği açısından, alüvyon gibi pekleşmemiş birimler için uygun olan NQ wire-line tipi 3 m'lik karotiyerlerle karotlu ilerleme yapılmış ve karot örnekleri alınmıştır. Daha sonra kuyu 4,5" (11,43 $\mathrm{cm}$ ) çaplı matkap ile taranarak genişletilmiş ve içerisine 88 mm'lik PVC boru indirilmiş, çakıllanmış ve kuyu kompresör ile geliştirilmiştir. Gözlem kuyusuna dönüștürülen bu kuyulara seviye kaydediciler yerleştirilerek yeraltısuyu izlemesinde kullanılmıştır. Açılan pompaj kuyularına ve 11 adet gözlem kuyusuna seviye kaydedici cihazlar konumlandırılmıștır. Seviye kaydediciler her saat seviye ölçümü alacak meteoroloji istasyonları ile eş zamanlı olarak veri alacak șekilde ayarlanmıștır. Seviye kaydedici yerleştirilen kuyuların dağılımı Şekil 4'de gösterilmiştir. Proje kapsamında alınan 20 adet seviye kaydedici, bir adet elektiriksel iletkenlik ve su seviyesini aynı anda ölçen CTD kaydedici ve iki adet barometrik hava basıncı kaydedici açılan pompaj ve gözlem kuyularına konumlandırılmıştır. Seviye kaydedicilerin kuyulara konumlandırma aşamaları Şekil 4'de sunulmuştur. Proje sahasında yapılan pompaj kuyularında pompaj testlerine başlanılmıștır. Pompaj testinde $5 \mathrm{~L} / \mathrm{s}$ üretim yapan dalgıç pompa, enerji sağlayıcı jeneratör, pompa 
debisinin ölçülmesi için hacmi belli kap, gözlem ve pompaj kuyusuna indirilen iki adet seviye kaydedici ile pompa testi gerçekleștirilmiştir. Pompaj kuyusuna indirilen seviye kaydedici her saniye ölçüm alacak şekilde ayarlanmıştır. parametreler hesaplanmıștır. Bunlara ek olarak DSİ tarafından yapılan ve akiferleri temsil eden kuyu verileri de elde edilerek akiferin hidrolik parametreleri haritalanmış ve akifer karekterizasyonu değerlendirilmiştir.

Elde edilen veriler Aquifer Test Programı kullanılarak değerlendirilmiş ve hidrolik

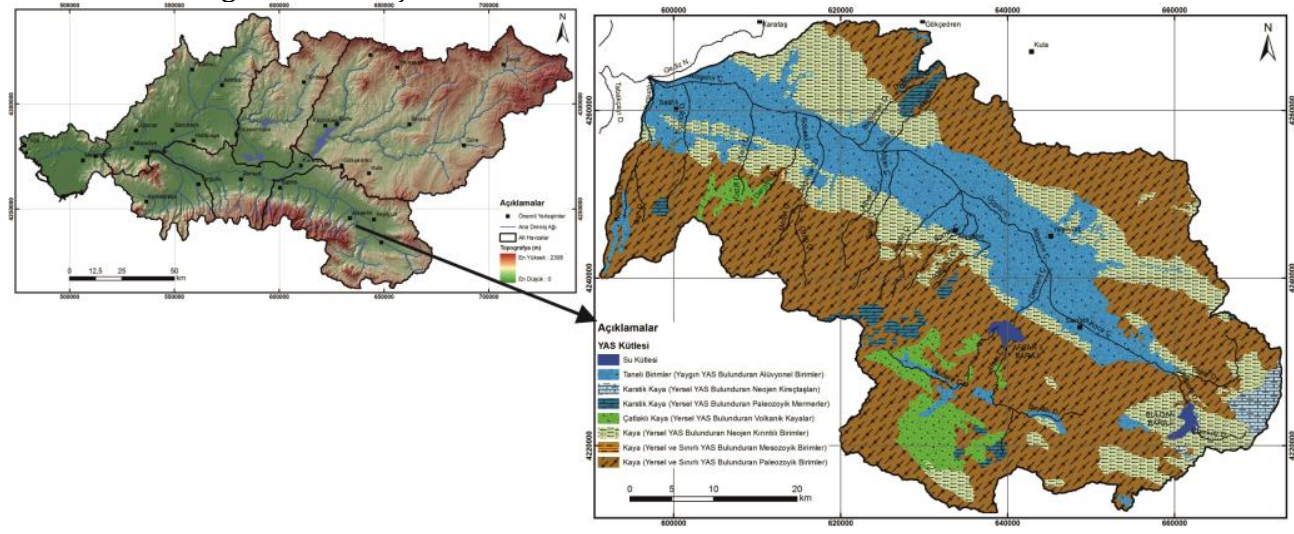

Şekil 1. C Çalışma alanının yeri ve hidrojeoloji haritası ([6]'dan alınmıștır)

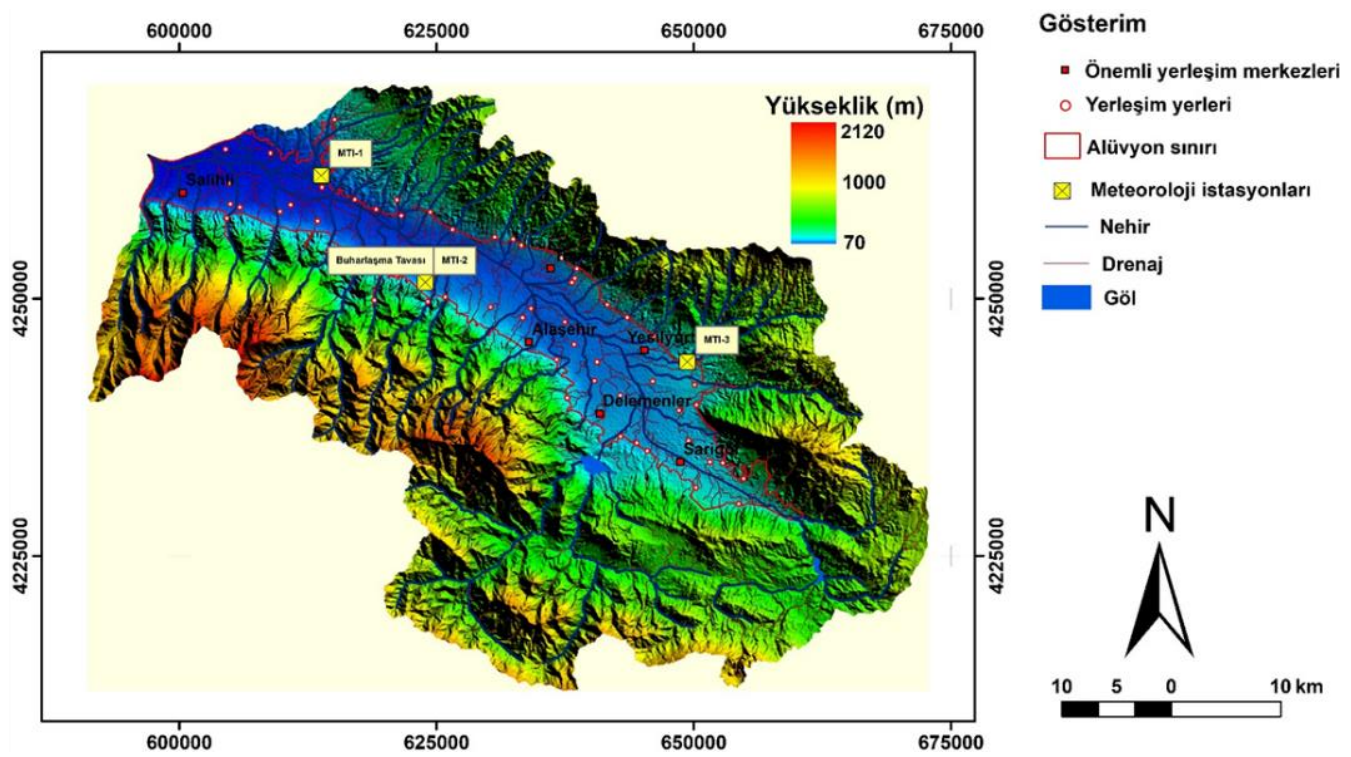

Şekil. 2. Proje sahasına konumlandırılan meteoroloji istasyonların yerleri 
DEÜ FMD 24(70), 91-104, 2022

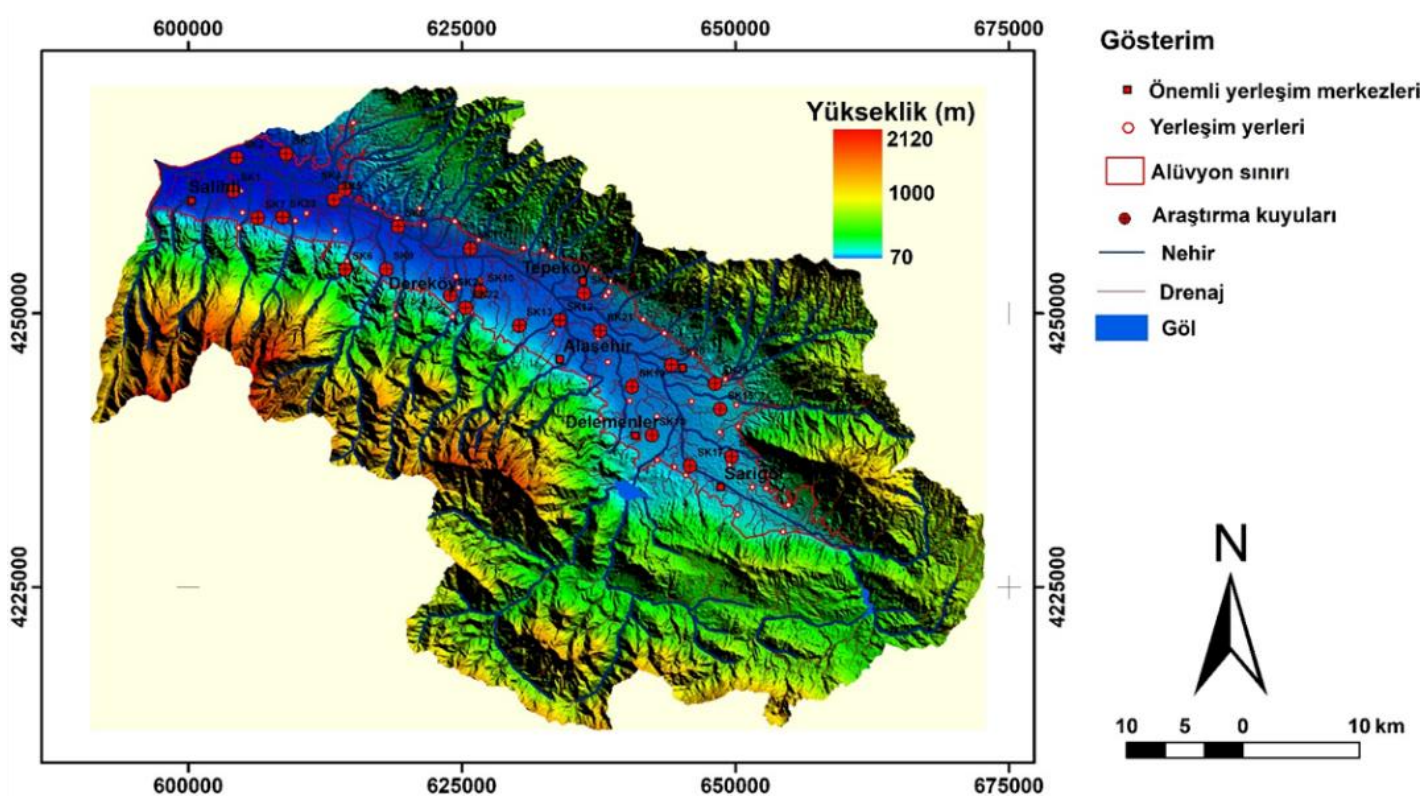

Şekil 3. Alüvyon akiferi temsil edecek noktalara açılmıș sondaj kuyu lokasyonları
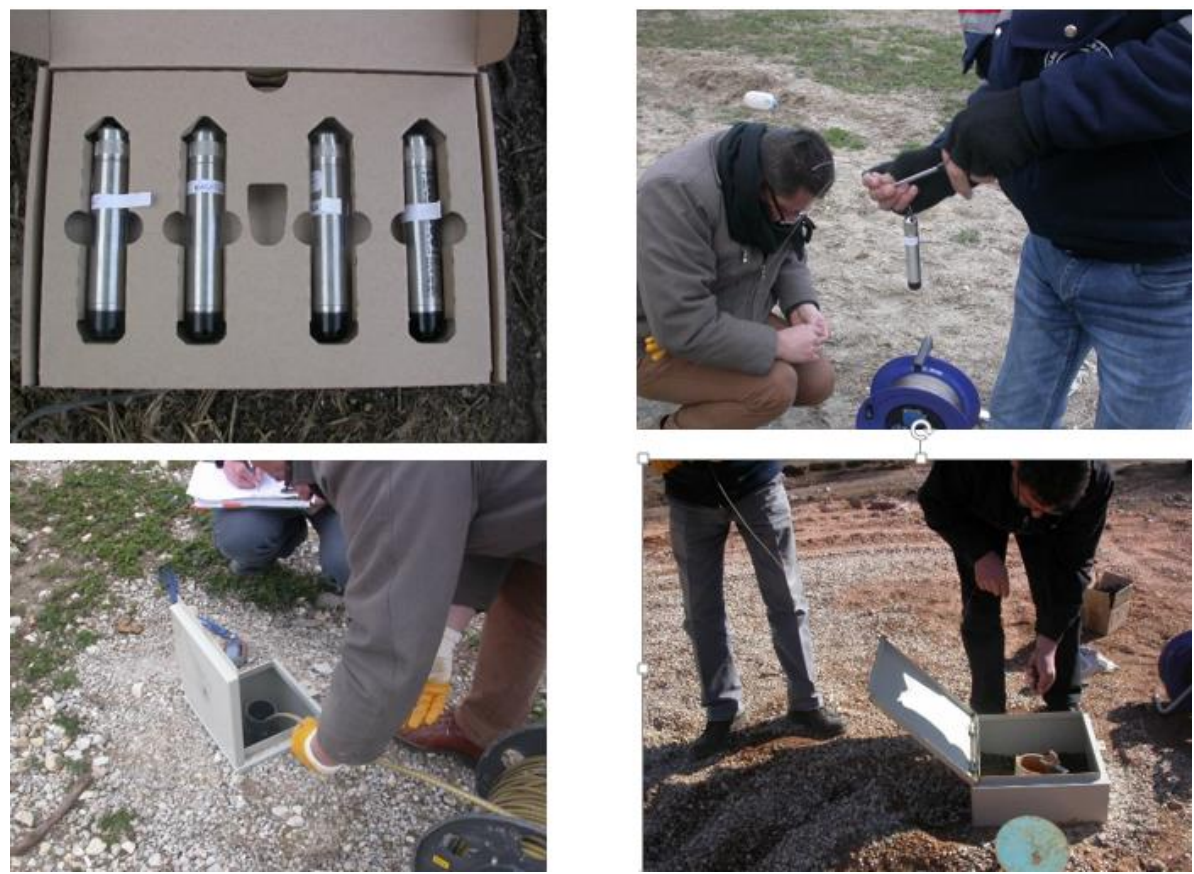

Şekil 4. Seviye kaydedicilerin kuyulara yerleştirilmesi 
DEÜ FMD 24(70), 91-104, 2022

\subsection{Yeraltısuyu Seviye Değişim Yöntemi}

Seviye değişim yöntemi ile akiferi temsil edecek noktalarda açılmış ve uzun dönem seviye izlemesi yapılmış olan kuyulardaki seviye değişimleri incelenerek beslenme miktarı hesaplanabilmektedir. Özellikle yağışlı dönemde akiferde depolanan su hacmin artışı yeraltısuyu seviyesinde yükselime neden olur. Bu yükselim dönemi baz alınarak akiferde yağışlı dönemde depolanan su miktarı ortaya konulabilmektedir. $\mathrm{Bu}$ yöntemin kullanılması için proje sahasına açılmış olan gözlem ve pompaj kuyularına seviye ölçerler monte edilerek her saat seviye ölçümü alınmıştır. Zamana bağlı olarak seviyelerin değișim grafiği oluşturulduğunda kurak dönem sonu ile yağışlı dönem sonu kolaylıkla ayırt edilebilmektedir. $\mathrm{Bu}$ cihazlardan alınan verilerin hidrolik yük cinsine dönüştürülmesi gerekmektedir. Bu işlem için gerekli olan veriler ise yalnızca hava basıncını ölçen otomatik hava basıncı ölçer ile sağlanmaktadır. Kuyu dışında bulunan bu sensörler yalnızca hava basıncını ölçmektedir. Sahamızda alana yayılmış şekilde 2 adet otomatik hava basıncl ölçer konumlandırılmıştır. Kuyuda su içerisinde bulunan sensördeki su basincı + hava basıncı verisinden, kuyu dişında bulunan otomatik hava basıncı ölçer ile alınmıș hava basıncı verisi çıkartılarak yalnızca su yükü bulunmaktadır. Elde ettiğimiz bu veri sensörün bulunduğu derinlikten daha sonra da kuyu kotundan çıkartılarak hidrolik yük elde edilmektedir.

$\mathrm{Bu}$ veriler zamana bağlı olarak grafiklendirilmiștir. Daha sonra ise yağış verileri eklenerek yağışlı dönemler ve seviyelerin minimum ve maksimum olduğu zamanlar ortaya konularak Eşitlik 1 ile beslenme (R) hesaplanabilmektedir (Şekil 5). Seviye değișim yöntemi yağıș, yüzey suyu ve yanal beslenim değerlerini yansıtan en önemli beslenme yöntemlerinden biri olarak bilinmektedir [9, 15 ve 16].

Burada, $S_{y}$; akiferin özgül verimi veya depolama katsayısı, $\Delta \mathrm{h}$ ise bir $\Delta \mathrm{t}$ zaman periyodunda su seviyesindeki değișimidir. Yükselim periyoduna göre beslenim miktarı Şekil 5'de sunulmuştur.

$$
\mathrm{R}=S_{Y} \times \Delta \mathrm{h} / \Delta \mathrm{t}
$$

Depolama katsayısı ise pompaj test verilerinden ve DSI [6] verileri kullanılarak depolama katsayısı dağılım haritası üretilmiştir. Burada bazı gözlem kuyularının hesaplanmıs depolama katsayısı olmaması nedeni ile raster harita verisi kullanılmıştır.

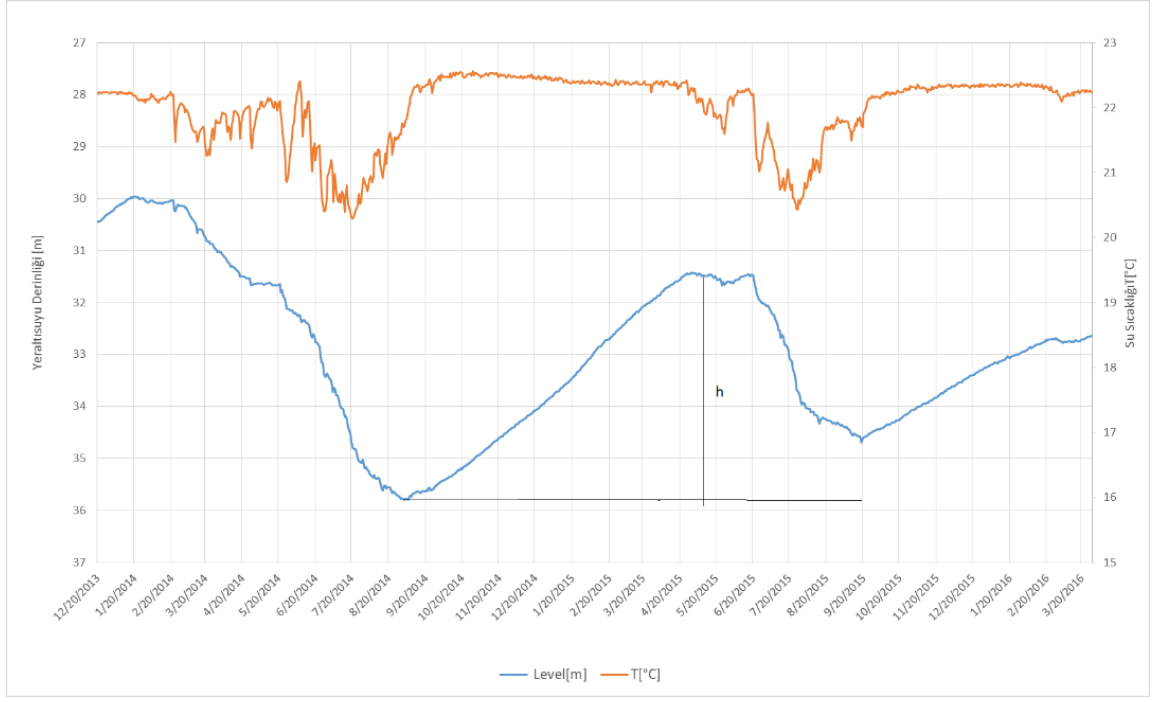

Şekil 5. Yağışlı dönemde yeraltısuyu yükselim miktarının belirlenmesi 


\section{Bulgular}

\subsection{Akiferin Özellikleri}

Araştırmaya konu olan alüvyon akiferi temsil edecek sayıda araștırma kuyuları açılmıș ve akiferin hidrolik parametrelerini de elde etmek için pompaj test kuyuları açılmıştır. Araştırma kuyularından alınan karotlar incelenmiș ve laboratuvarda yapilan Zemin sinıflama deneylerinde zemin sınıfları da elde edilmiștir. $\mathrm{Bu}$ verilere göre, akiferin batı kesimlerinde iri daneli çakıl ve kum ağırlıklı zeminler hakim iken, doğu ve güney doğu kesimlerinin ise kil ve silt ağırlıklı malzemeden oluştuğu alınan karot örneklerinden anlaşılmıștır. Akiferin hidrolik parametrelerinin belirlenmesi için proje sonucunda elde edilen veriler ile DSİ tarafından yapılmış çalışmadan çıkan sonuçlarla bir istatistik bilgisi oluşturulmuştur (Tablo 1). Burada özellikle seviye değişim yöntemi için gerekli olan depolama katsayısı değeri her kuyuda hesaplanamadığından eldeki verilerden bir dağılım haritası olușturulmuș ve diğer kuyular için depolama katsayısı haritadan elde edilmiștir (Şekil 7).

Depolama katsayısının hesaplanması için pompaj kuyusunun yakınına bir seviye izleme kuyusu açlması gerekmektedir. Proje kapsamında açılan 10 adet pompaj kuyusu ve DSİ tarafından yapılan bir kaç kuyu verisi kullanılmıştır. $\mathrm{Bu}$ değerler ışığında, akiferin geçirgenlik değeri 0,02 ile $68,27 \mathrm{~m} / \mathrm{g}$ arasında değişmektedir. Depolama katsayısı 0,0004 ile 0,34 arasında değişmektedir. Akiferin iletimliliğinin ise 7,31 ile $5694 \mathrm{~m}^{2} / \mathrm{g}$ arasında değiştiği saptanmış ve en yüksek iletimlilik değerinin doğu alüvyonel yelpazelerde olduğu tespit edilmiştir. Alüvyon akifer için özgül debi değeri 0,09 ile 26,43 L/s/m arasında değișmekte olup ortalaması $4,3 \mathrm{~L} / \mathrm{s} / \mathrm{m}$ olarak elde edilmiștir. Alüvyon akiferin malzeme özelliğine göre çok geniș bir aralıkta özgül debi değeri sunmaktadır.

Proje sahasından elde edilen Hidrolik iletkenlik ve Özgül debi değerleri arasında bir korelasyon olup olmadığı araștırılmıștır. Yapılan korelasyon hesaplamalarında korelasyon katsayısı (r) değeri 0,85 bulunmuş olup, doğrusal ve yüksek bir ilişki ortaya çıkmıştır [17]. Elde edilen hidrolik parameterelere göre alüvyon akifer serbest akiferin niteliği taşıdığı ve yeraltısuyunun yağıșlardan sonra hızlı tepki vereceği bir yapıya sahip olduğu ortaya konmuştur.

\subsection{Seviye Değişim Yöntemine Göre Yeraltısuyu Beslenimin Belirlenmesi}

Sahada açılan kuyulara yerleştirilen otomatik seviye ölçerler her saat bașı veri alarak kaydetmiştir. Kuyulardan elde edilen seviye eğrilerinden bazıları Şekil 6'da sunulmuştur. Ayrıca sahaya konumlandırılan 3 adet meteoroloji istasyonlarında seviye kaydediciler ile aynı zaman sürelerinde yağıș miktarını kaydetmiştir. Aynı grafikte seviye değişimi ve yağıș değerleri zamana bağlı olarak sunulmuştur. Seviye eğrilerine bakıldığında en düşük seviyenin kurak dönem olan Ekim ayında hidrolik yükün en düșük olduğu zaman olarak elde edilmiştir. Ekim ayından itibaren yağıșların başlaması ve sulama suyu çekimlerinin azalmasına bağlı olarak Mayıs ayına kadar su seviye yükselim sunmuştur. Bazı kuyularda Mart ayında, bazı kuyularda ise Mayıs ayına kadar yükselimi gözlenmiştir. Bu yükselimin kuyuların bulunduğu lokasyona bağlı olarak ve malzeme geçirgenliği ile ilişkili olduğu düşünülmektedir. Seviye değişim yönteminin en önemli özelliği seviyenin yağıș, yüzey sularından süzülme ve yanal su girișlerini seviyeye etki yapmasıdır. $\mathrm{Bu}$ nedenle kuyulardaki seviye yükselim piklerinde farklılıklar olabilmektedir. Kuyu seviye değișimlerinden elde edilen en düșük ve en yüksek hidrolik yük değerleri ve aralarındaki zaman grafiklerden elde edilmiş ve Tablo 2'de sunulmuștur. Bu verilere göre alüvyon akiferin yllık beslenim miktarı $39,6 \mathrm{~mm}$ ile $588,99 \mathrm{~mm}$ arasında değișmekte ve ortalama olarak 290,04 $\mathrm{mm}$ olarak hesaplanmıștır. Alüvyon akiferde açılan PM-2 ve PM-4 nolu kuyuların fişkırması nedeni ile kapatılmış bu nedenle beslenme hesabında kullanılamamıștır.

Seviye değişim modelinde yeraltısuyu seviyesinin yağıștan sonra veya yağıșlı dönemde yağıșa tepki vermesi gerekmektedir. $\mathrm{Bu}$ bağlamda yağışların yeraltısuyu seviyesine ulaşmasına olanak sağlayacak geçirimli zeminlerin olmaması beslenme miktarını etkilemektedir. Açllan kuyuların büyük çaplı çekim kuyularından uzağa açılması nedeni ile kuyu çekimlerinden etkilenmemesi sağlanmaya çalışılmıştır. Bazı kuyularda belirlenen yeraltısuyu seviyesindeki küçük dalgalanmaların farklı zeminlerin ardalanmalı kesilmesinden kaynaklandığı düşünülmektedir. 
Buna karşılık diğer gözlem noktalarından elde edilen seviye verilerinin hem yağıșlı dönemde beslenmeye hem de kurak dönemde çekimlere tepki verdiği görülmektedir. Bu bağlamda diğer izleme noktalarının alüvyon akiferde seviye değișim yöntemine göre elverișli veri oldukları anlaşılmaktadır. $\mathrm{Bu}$ kuyulardan $\mathrm{PM}-10$ ise yüzeysuyuna yakın olan bir kuyudur. Kuyunun yağıșlara çok hızlı tepki verdiği görülmektedir. Yağıșlardan sonra diğer kuyulara nazaran daha fazla seviyelerde değișimler izlenmiștir. $\mathrm{Bu}$ değişimler yüzey sularının yağışlı dönemde akiferi beslediğini ifade etmektedir. Seviye değișim yönteminin en önemli özelliklerinden biri akiferdeki su hacmini değiștiren yağıșdan süzülme, yüzeysel sularından süzülme, yanal beslenme ve sulama sularının katkıların içeren toplam içe akışı ifade etmesidir. Bu iki kuyuda elde edilen beslenme miktarlarının diğer kuyulardan elde edilenlere göre oldukça yüksek olduğu görülmektedir. Bu bağlamda yüzey sularının da alüvyon akiferin beslenimde önemli bir rol oynadıkları anlaşılmaktadır.

Şekil 8'de yeraltısuyu seviye değişim yönteminden elde edilen noktasal beslenme değerleri kullanılarak dağılım haritası elde edilmiştir. Alüvyon akiferde beslenme miktarının alanın batı kesimlerinde alüvyon yelpazelerin olduğu alanlarda yüksek olduğu görülmektedir. Alanın batı kesimleri yüksek topoğrafyaya sahip olması nedeni ile alüvyonel malzeme dağılımı iri daneli ve geçirimli malzemeden olușmaktadır. Bunlara ek olarak batı kesimlerde yoğun yüzeysel drenaj alanı gelişmekte ve bu drenaj ağından gelen yüzey suları alüvyonu besleyen bir mekanizma sunmaktadır. Bu bağlamda yanal beslenme miktarı da dikkate alındığında batı kıyı kesimlerde beslenme değeri yüksek elde edilmiştir. Alanda batı kesimler önemli yeraltısuyu içeren beslenme ve boșalım mekanizması yüksek bir akifer zonuna ișaret etmektedir.

Elde edilen ortalama beslenme değerinin DSI 2014 yılında yapılan yağıș ve seviye yükselim korelasyonuna göre elde edilen $265 \mathrm{~mm}$ beslenme değerine yakındır. İki beslenme değeri arasındaki fark, bu çalıșmada akiferi temsil edecek sayıda kuyu ile beslenim değeri hesaplanmış, DSİ [6] çalışmasında ise bir kuyu verisine göre belirlenmiș olmasıdır. Bu nedenle alüvyon akiferde beslenme değeri 39,6 mm ile $588,99 \mathrm{~mm}$ arasında değişmektedir. Bu değerler akiferin heterojen olması nedeni ile oldukça olağandır. Tek kuyu verisi tüm akiferi temsil etmemekte ve yeraltısuyu potansiyelinin belirlenmesinde yeterli veri sağlamamaktadır.

Tablo 1. Alüvyon akiferin hidrolik parametre ortalamaları $(n=65)$

\begin{tabular}{cccc}
\hline $\mathrm{T}(\mathrm{m} 2 / \mathrm{d})$ & $\mathrm{K}(\mathrm{m} / \mathrm{d})$ & Ozgül Debi $(\mathrm{L} / \mathrm{s} / \mathrm{m})$ & Depolama Katsayısı \\
\hline 7,31 & 0,02 & 0,0859 & 0,0004 \\
5694,00 & 68,27 & 26,4317 & 0,3420 \\
782,03 & 9,05 & 4,2948 & 0,0702 \\
\hline
\end{tabular}


DEÜ FMD 24(70), 91-104, 2022
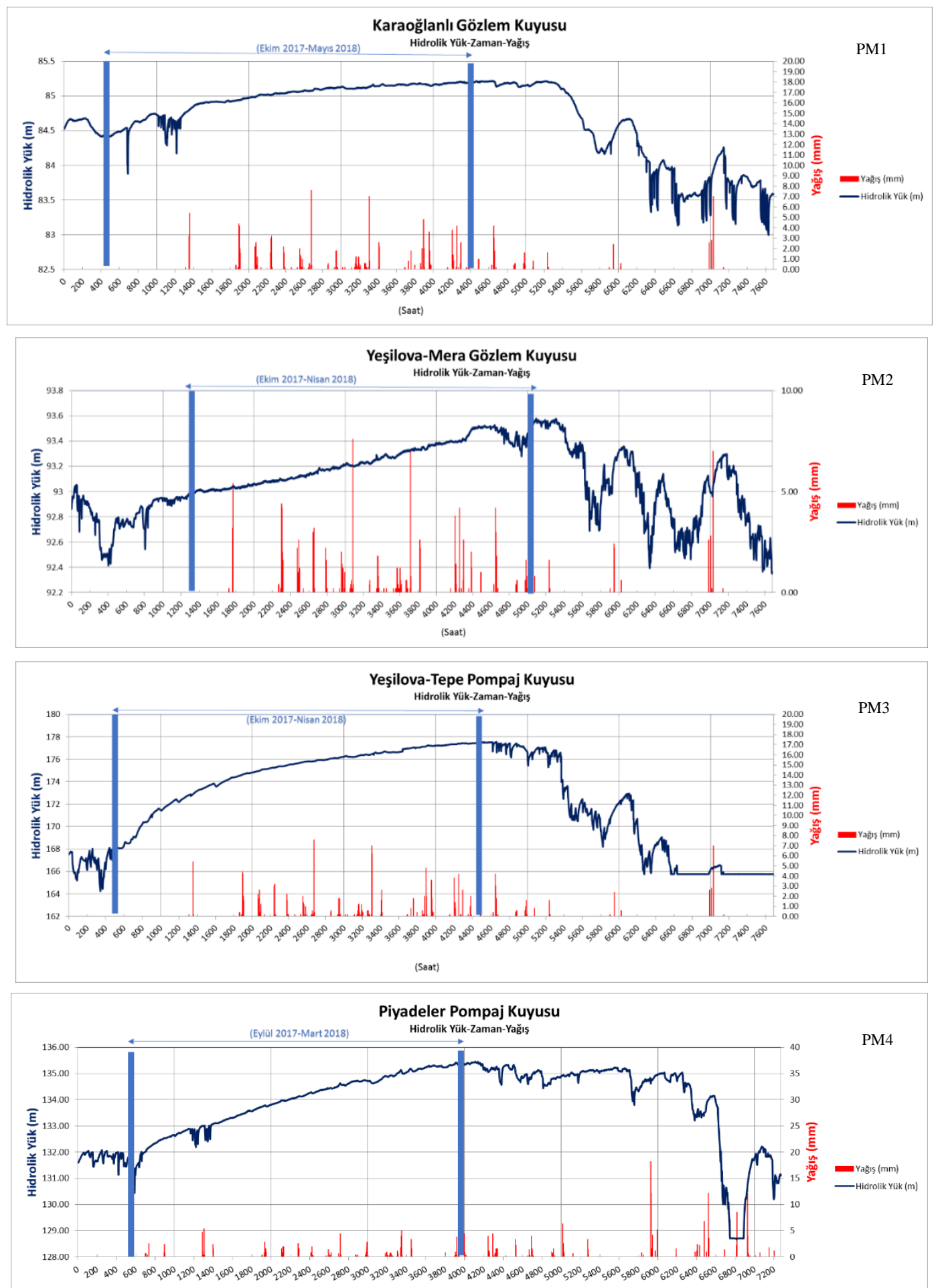

Şekil 6. Yeraltısuyu Seviye Kaydedicilerden alınan seviye yükselim verileri 
DEÜ FMD 24(70), 91-104, 2022
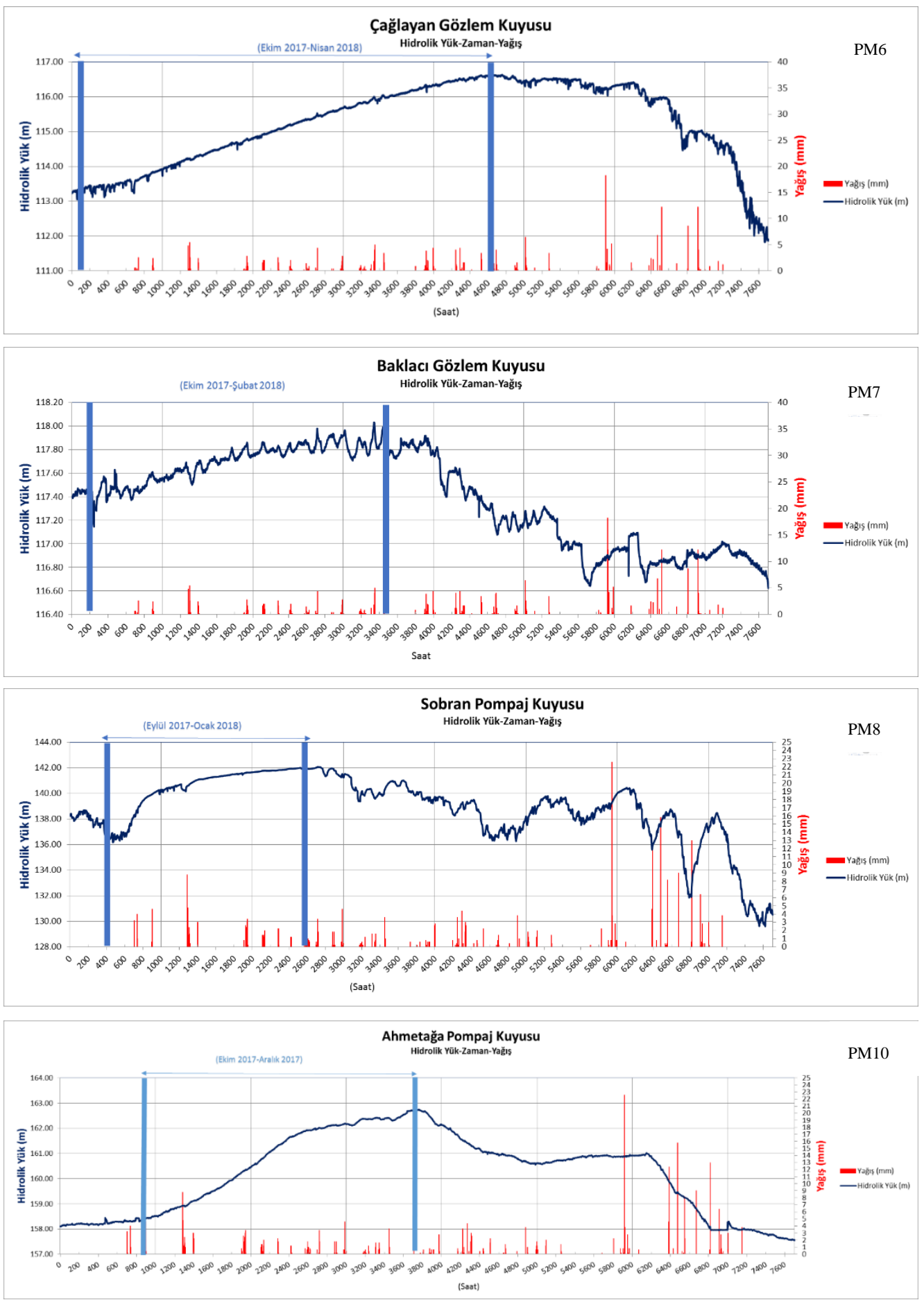

Şekil 6 (devam) 
DEÜ FMD 24(70), 91-104, 2022
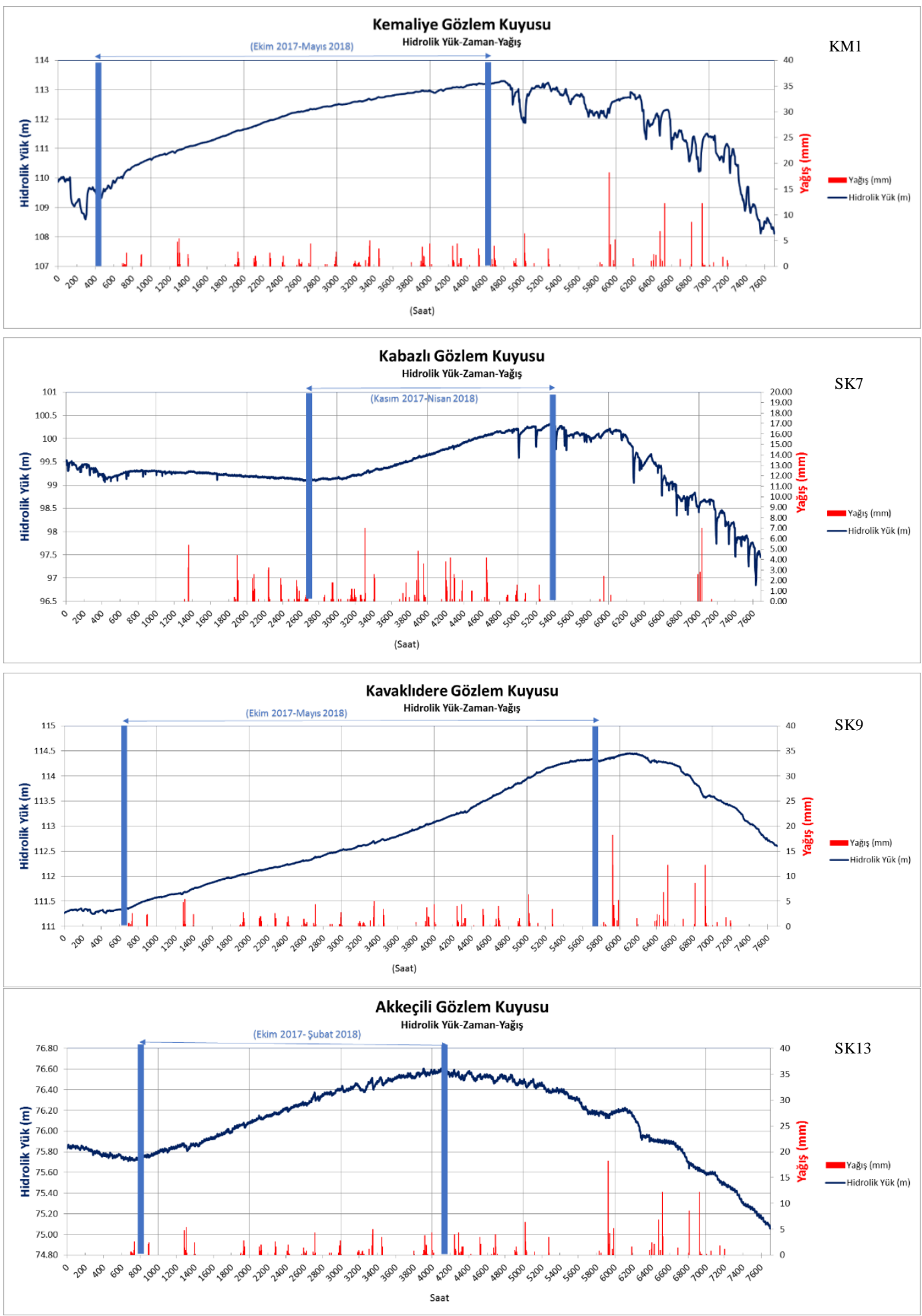

Şekil 6 (Devam) 
DEÜ FMD 24(70), 91-104, 2022

Tablo 2. Seviye yükselim değerlerinden elde edilen zaman ve beslenim miktarları

\begin{tabular}{|c|c|c|c|c|c|c|c|c|c|c|}
\hline Kuyu No & $\mathrm{x}$ & $y$ & z & $\begin{array}{c}\text { Derinlik } \\
\text { (m) }\end{array}$ & Kuyu Tipi & $\begin{array}{c}\text { Maks.Hidrolik } \\
\text { Yük (m) }\end{array}$ & $\begin{array}{c}\text { Min.Hidrolik } \\
\text { Yük (m) }\end{array}$ & $\begin{array}{c}\text { Zaman } \\
\text { (gün) } \\
\end{array}$ & $\begin{array}{l}\text { Depolama } \\
\text { Katsayısı }\end{array}$ & $\begin{array}{c}\text { Beslenme } \\
(\mathrm{mm})\end{array}$ \\
\hline SK2 & 604422 & 4264194 & 101 & 30 & Gözlem & 83,72 & 83,53 & 162 & 0,09 & 39,61 \\
\hline SK7 & 606070 & 4252503 & 131 & 50 & Gözlem & 100,3 & 99,09 & 112 & 0,1 & 407,00 \\
\hline SK8 & 619179 & 4257930 & 115 & 41 & Gözlem & 106,03 & 105,4 & 161 & 0,07 & 102,28 \\
\hline SK9 & 618086 & 4254018 & 143 & 46.5 & Gözlem & 114,33 & 111,37 & 206 & 0,07 & 374,50 \\
\hline SK11 & 625770 & 4255886 & 125 & 50 & Gözlem & 109,56 & 107,61 & 132 & 0,06 & 319,40 \\
\hline SK13 & 630254 & 4248858 & 101 & 50 & Gözlem & 76,6 & 75,71 & 140 & 0,06 & 132,50 \\
\hline SK14 & 636158 & 4251807 & 148 & 50 & Gözlem & 123,96 & 123 & 153 & 0,05 & 240,90 \\
\hline SK14 & 636158 & 4251807 & 148 & 50 & Gözlem & 123,38 & 122,02 & 154 & 0,05 & 159,52 \\
\hline SK22 & 625345 & 4250473 & 171 & 50 & Gözlem & 135,41 & 131,87 & 144 & 0,06 & 529,12 \\
\hline PM-1 & 604153 & 4261163 & 95 & 70 & Pompaj & 85,21 & 84,41 & 174 & 0,1 & 164,70 \\
\hline PM-3 & 613351 & 4260371 & 164 & 100 & Pompaj & 93,57 & 93,02 & 150 & 0,08 & 106,50 \\
\hline PM-6 & 623982 & 4251766 & 188 & 100 & Pompaj & 116,62 & 113,22 & 194 & 0,065 & 411,13 \\
\hline PM-7 & 633948 & 4249355 & 148 & 100 & Pompaj & 118 & 117,4 & 139 & 0,05 & 83,70 \\
\hline PM-8 & 640552 & 4243264 & 170 & 100 & Pompaj & 142,05 & 136,09 & 97 & 0,01 & 220,57 \\
\hline PM-10 & 645856 & 4236078 & 188 & 100 & Pompaj & 162,74 & 159,17 & 96 & 0,04 & 532,20 \\
\hline KM-1 & 621611 & 4263910 & 122 & 60 & Üretim & 113,2 & 109,04 & 192 & 0,07 & 523,12 \\
\hline \multirow[t]{4}{*}{ GR-1 } & 624796 & 4252731 & 150 & 80 & Üretim & 121,33 & 114,83 & 168 & 0,04 & 583,99 \\
\hline & & & & & Min & 76,60 & 75,71 & 96,00 & 0,01 & 39,61 \\
\hline & & & & & Max & 162,74 & 159,17 & 206,00 & 0,10 & 583,99 \\
\hline & & & & & Ortalama & 113,29 & 110,99 & 151,41 & 0,06 & 290,04 \\
\hline
\end{tabular}

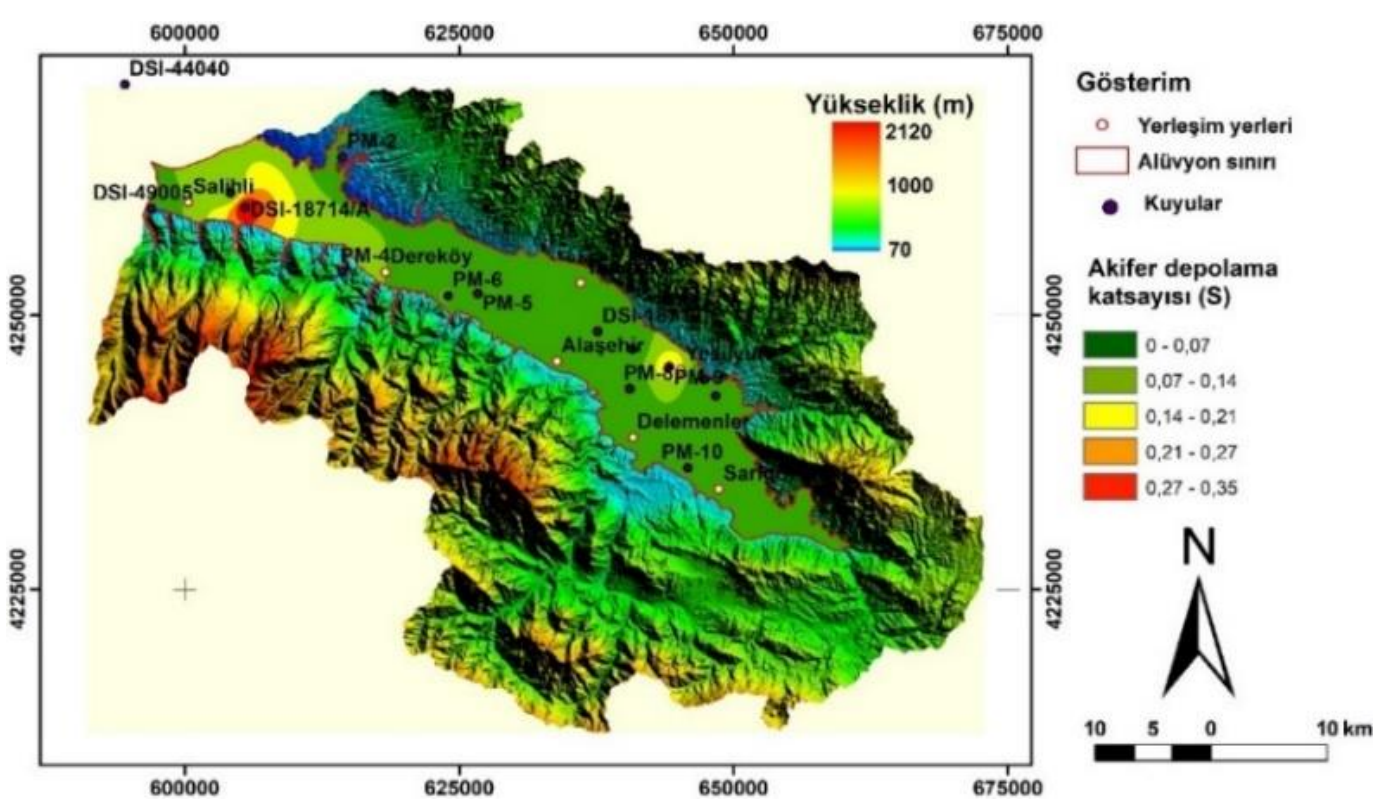

Şekil 7. Akifer depolama katsayısı dağılım haritası 


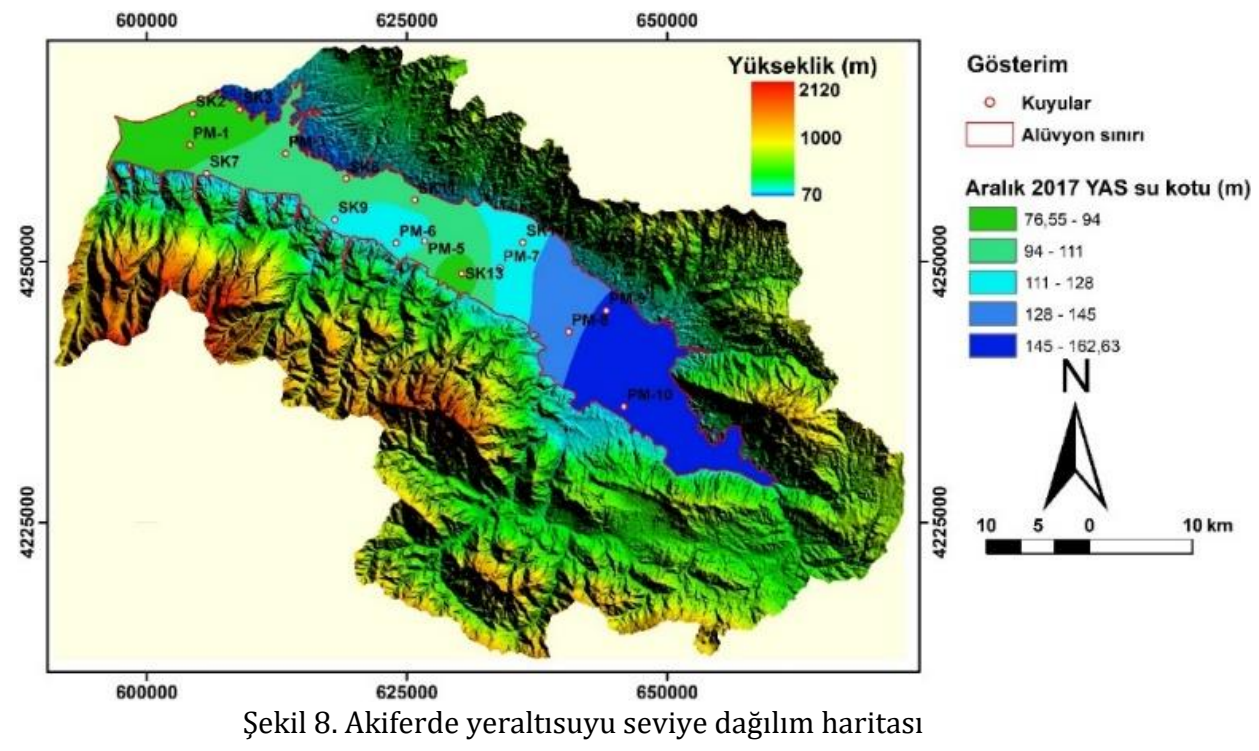

\section{Tartışma ve Sonuç}

$\mathrm{Bu}$ çalışmada Alaşehir alüvyon akiferinde yeraltısuyu besleniminin belirlenmesi için seviye değişim yöntemi ile elde edilen yıllık yeraltısuyu beslenim değerleri belirlenmiștir. $\mathrm{Bu}$ kapsamda yapılan sondaj çalışmalarında alüvyon akiferin geçirimli ve yağıșlara hızlı tepki veren bir sisteme sahip olduğu belirlenmiştir. Proje alanı olarak seçilen akifer uygulanan yöntem için uygun bir akifer niteliğindedir. Proje sahasında olușturulan meteoroloji ve yeraltısuyu izleme ağı verileri kullanılarak seviye değişim yöntemi ile alanda en düşük su seviyesinin Ekim 2017, en yüksek su seviyesinin ise Mayıs 2018 aylarında olduğu görülmektedir. Sahada açılan pompaj ve gözlem kuyularına konumlandırılan 17 adet seviye izleme verisi sonuçlarına göre akiferin yıllık beslenim değerinin $39,6 \mathrm{~mm}$ ile 588,99 $\mathrm{mm}$ arasında değișmekte olduğu ve ortalama olarak 290 mm'lik bir yıllık beslenim miktarına sahip olduğu hesaplanmıştır. En yüksek beslenme miktarı jeolojik yapıya uyumlu olarak alanın batı kesimlerindeki geçirimli malzemelerin, alüvyonel yelpazelerin dağılım sunduğu alanlarda belirlenmiștir.

Uygulanan yöntem uzun dönem yeraltısuyu seviyesinin kullanımı ile yağıșlı dönemde akifer depolamasındaki su hacminin artmasına bağlı olarak seviyedeki yükselimlerin beslenme olarak ele alındığı bir yöntemdir. Ülkemizde de bu yöntem DSİ tarafından akiferlerin beslenim miktarının belirlenmesi için açılan rasat kuyuları verileri ile uygulanmaktadır. Ancak açılan rasat kuyuları akiferi temsil edemeyecek şekilde oldukça sınırlıdır. Bu noktasal bulgular tüm akiferdeki beslenme miktarını yansıtamamaktadır. Bu nedenle, söz konusu yöntemin uygulanması için akiferi temsil edecek çok sayıda kuyu verisine ihtiyaç duyulmaktadır. $\mathrm{Bu}$ yöntemin uygulanması için göz önünde bulundurulması gereken sınırlamalar şunlardır; yeraltısuyu seviyesi yüzeye yakın olmalı $(<30$ m), yağışa tepki verecek derinliklerde olmalı, gözlem kuyularından seviye izlenmeli, açlan kuyu çevresinde pompaj ve çekim kuyuları olmamalı, barometrik etki göz önüne alınmalı ve akifer depolama katsayısı mutlaka belirlenmelidir.

Yukarıdaki sınırlamalar ele alındığında bu yöntem yaygın akifer özelliği sunan alüvyon akiferlerde kullanılabilir bir yöntem olarak karşımıza çıkmaktadır. Ancak, noktasal beslenmeli veya basınçlı akifer sistemlerinde uygulanabilir olup olmadığı araştırılması gerekmektedir. Proje sahasındaki alüvyon akiferde izlenen seviye değişimlerinin yağıșlı ve kurak dönemleri yansıttığı belirlenmiştir. Bu tür değişim eğrileri ile seviye değișim yönteminden yeraltısuyu beslenme miktarı kolaylıkla belirlenebilmektedir. İnceleme alanında yapılan farklı yöntemlerle tespit edilen yağıștan süzülme miktarı karșılaștırılmıștır. Sahada 25 adet 
karotlu sondaj verisi kullanılarak düșey yönlü sızmanın hydrus modeli ile yapılan çalıșmada elde edilen yağıştan süzülme miktarı 21,78 ile $68,52 \mathrm{~mm}$ ve ortalaması $43 \mathrm{~mm}$ olarak hesaplanmıştır [13]. Yine aynı sahada bașka bir yöntemle beş noktada konumlandırılan zemin nem ölçümleri ile elde edilen yağıștan süzülme miktarı belirlenmiş ve ortalama olarak 56,83 mm hesaplanmıştır [14].

Aynı sahada farklı yöntemlerle elde edilen yüzeysel yağıștan süzülme miktarlarının birbirine yakın değerlerde olduğu görülmektedir. Seviye değișim yönteminde ise

\section{Teşekkür}

Bu çalışma Türkiye Bilimsel ve Teknolojik Araştırma Kurumu (TÜBİTAK) tarafindan, 115 Y065 nolu proje kapsamında desteklenmiștir.

\section{Kaynakça}

[1] Kapluhan E. 2013. Türkiye'de Kuraklik Ve Kurakliğin Tarima Etkisi. Marmara Coğrafya Dergisi Sayi: 27, Ocak - 2013, S. 487-510 İstanbul - Issn:1303-2429

[2] Margat, J. Vander Gun, J. 2013. Groundwater around the World: A Geographic Synopsis. CRC Press/Balkema. Leiden.

[3] Salameh E. 2008. Over-exploitation of groundwater resources and their environmental and socioeconomic implications: the case of Jordan. Water International. 33:1

[4] Günay, G. 2010. Chapter 10.6 - Case Study: Geological and hydrogeological properties of Turkish karst and major karstic springs. Groundwater Hydrology of Springs Engineering, Theory, Management, and Sustainability Pages 479-497

[5] SYGM, 2020. Kuzey Ege Havzası Master Plan Raporu Su Yönetimi Genel Müdürlügüu, Ankara

[6] DSİ 2014. DSİ 02 Bölge Gediz Havzası Yeraltısuyu Planlaması Hidrojeolojik Etüd Raporu, DSİ Ankara

[7] Şimşek C, Demirkesen A.C., Baba A., Kumanlığlu A. Durukan S., Aksoy N, Demirkıran Z, Hasözbek A Murathan A., Tayfur G., 2020. Estimation groundwater total recharge and discharge using GIS-integrated water level fluctuation method: a case study from the Alașehir alluvial aquifer Western Anatolia, Turkey, Arabian Journal of Geosciences, 2020: 13/143

[8] DSİ, 2020. Devlet Su İşleri Genel Müdürlüğü. http://www.dsi.gov.tr/

[9] Healy, R.W., Cook, P.G. 2002. "Using groundwater levels to estimate recharge".Hydrogeology Journal 10(1), 91-109.

[10] Scanlon BR, Healy RW, Cook PG. 2002. “Choosing appropriate techniques for quantifying groundwater recharge". Hydrogeol J 10:18-39 yeraltısuyu beslenimi ortalama $290 \mathrm{~mm}$ olarak hesaplanmıştır. Yüzeyden süzülme yöntemleri sadece yağıştan süzülme miktarını verirken, seviye değișim yöntemi yüzeyden yağıș süzülmesi, yüzey suyu süzülmesi ve yanal olarak akifer beslenmesini de içermektedir. $\mathrm{Bu}$ bağlamda seviye değișim yöntemi zaman alıcı ve uzun dönem izleme gerektiren bir yöntem olmasına karşın akiferdeki içe akışı daha doğruya yakın hesaplamamıza yardımcı olan bir yöntem olarak karşımıza çıkmaktadır. Burada yanal ve yüzeysel su kaynaklarından da önemli oranda akifere içe akış olduğu anlaşılmaktadır.

[11] White, W. B. 2002. "Karst hydrology: recent developments and open questions", Eng. Geol., 65, 85-105

[12] Leaney, F., Crosbie, R., O'Grady, A., Jolly, L., Gow, L., Davies, P., Wilford J., Kilgour. P. 2011. " Recharge and Discharge Estimation in Data Poor Areas Scientific Reference Guide, Avustralian Goverment. National Water Comission. CSIRO": Water for a Healthy Country National Research Flagship. 61 pp.

[13] Tonkul S, Baba A, Şimşek C, Durukan S, Demirkesen AC,Tayfur G. 2018. Groundwater recharge estimation using HYDRUS 1D model in Alașehir subbasin of Gediz Basin in Turkey

[14] Durukan S, Şimşek C , Tonkul S , Baba A, Tayfur G., 2021 Alassehir Alt Havzasının (Gediz Havzası, Batı Anadolu) Nem Değişimi Yöntemine Göre Yeraltısuyu Besleniminin Değerlendirilmesi. Dokuz Eylül Üniversitesi Fen ve Mühendislik Dergisi.23/11-23

[15] Acar R., Sayıner İ. 2008. "Kuyu rasatlarından ve yağışlardan faydalınarak Erzurum Ovasının Yeraltısuyu Bilançosunun hesaplanamsı". Atatürk Ünv. Ziraat Fak. Derg. 39 (1), 93-100.

[16] Korkmaz, N. 1988. "Kütahya Çavdarhisar Ovasında Kuyu ve Yağış Rasatlarından Faydalanılarak Süzülme Miktarının Hesaplanması". DSİ Bülteni Sayı 65,say 47-54

[17] Șimșek, C., Baba, A., Aksoy, N., Demirkıran, Z., Hasözbek, A., Tayfur, G., Kumanlıoğlu, A., Durukan, S., Demirkesen, A.C., Murathan, A., Cağıran, Ö., Akdeğirmen, Ö., Tonkul, S. 2017. Investigation of Groundwater Recharge Mechanism in Alaşehir Plain: From Physical Characterization to Modelling. 2nd Regional IWA Symposium on Water, Wastewater and environment, Çeşme, İzmir 